\title{
POLLEN COUNTS IN SLAVONSKI BROD, CROATIA DURING THE POLLINATION PERIOD 2008 TO 2010
}

\author{
Martina NADIH, Zvonimira MEDVEREC KNEŽEVIĆ, Renata JOSIPOVIĆ, \\ Ivanka GRGIĆ, and Ante CVITKOVIĆ \\ Institute of Public Health of Brod - Posavina County, Slavonski Brod, Croatia \\ Received in June 2011 \\ CrossChecked in June 2011 \\ Accepted in October 2011
}

\begin{abstract}
Hay fever or pollinosis is the allergic reaction of the human body to allergic pollen grains and is a seasonal phenomenon. Pollen concentrations depend on the climate, geographic features, and vegetation. Trees, grass, and weed pollinosis is frequent in Croatia, common ragweed (Ambrosia artemisifolia L.) pollinosis in particular. Continuous monitoring of pollen air concentrations can provide timely information to the general public and can help sensitised patients and their physicians to prevent or alleviate allergic reactions. This is the task of health ecology services such as our Public Health Institute of the Brod-Posavina County. This article reports pollen concentrations in Slavonski Brod measured in March 2008 to November 2008, March 2009 to October 2009, and April 2010 to October 2010 and discusses the increasing exposure to ragweed and ways to control it.
\end{abstract}

KEY WORDS: aerobiology, allergy, Europe, grass pollinosis, ragweed, tree pollinosis, weed pollinosis

Europe faces an increasing incidence of pollen allergy, particularly in the urban areas (1). Hay fever or pollinosis is the allergic reaction of the human body to allergenic pollen grains and is a seasonal phenomenon (2). From spring to autumn, pollen is in the air and its concentrations depend on the climate, geographic features, and vegetation (3-6). Pollinosis in Croatia is between the typical Mediterranean and central European, with grass (central European) and cypress pollen (Mediterranean) as the most frequent causes of pollinosis (1). Over the past few years, however, Croatia has seen a strong increase in the pollination of common ragweed (Ambrosia artemisiifolia L.), the source of the most potent pollen allergen in the country (7).

Information about the levels of pollen grains in the air could be very useful for sensitised patients and physicians, as it can improve prevention and therapy of seasonal allergic symptoms (9-11).

The aim of this study was to establish air levels of tree, grass, and weed pollens in Slavonski Brod during pollination in 2008 to 2010.

\section{METHODS}

This study reports pollen concentrations in Slavonski Brod measured in March 2008 to November 2008, March 2009 to October 2009, and April 2010 to October 2010. For pollen sampling we used a sevenday Hirst-type volumetric pollen and spore trap (Lanzoni s.r.l., Italia) (12). The sampler was placed on the roof of the general hospital "Dr Josip Benčević" in Slavonski Brod. It uses a vacuum-pump to pass $10 \mathrm{~L}$ 
of air through the orifice ( $2 \mathrm{~mm} \times 14 \mathrm{~mm}$ ) always directed into the wind. Inside is a drum with a tape coated with silicon oil to catch pollen grains. This adhesive tape moves at the speed of $2 \mathrm{~mm} \mathrm{~h}^{-1}$. Twice a week (on Mondays and Thursdays), we removed this tape, cut it to $48 \mathrm{~mm}$ strips that correspond to 24-hour pollen sampling. The strips were placed on glass slides and embedded in a medium prepared by dissolving $70 \mathrm{~g}$ polyvinil alcohol (Gelvatol, Burkard Scientific, UK) with $4 \mathrm{~g}$ phenol (p. a., Kemika, Croatia), in $200 \mathrm{~mL}$ of distilled water. After the overnight rest, $100 \mathrm{~mL}$ of glycerol (GRAM-MOL d.o.o., Croatia) was added and warmed up in a water bath until the solution turned liquid and clear. Then we added four drops of alcohol solution of basic fuchsin (Kemika, Croatia) per $100 \mathrm{~mL}$ of the medium. Two hours later, samples were examined under a light microscope (Olympus Corporation, Japan) at 400x magnification to determine pollen type against laboratory standards and bibliographical sources (1316) and count per day. Pollen count is the number of pollen grains per cubic meter of air. We compared the pollen count with a standard pollen rating scale (PRS, Table 1) to determine whether it was low, moderate, high, or very high $(17,18)$.

The start of the pollen season was defined as the first date on which at least one pollen grain per cubic meter of air was recorded for at least five consecutive days (19).

\section{RESULTS}

We identified 25 pollen taxa with moderate and highly allergenic grains, including: Abies (fir), Aesculus (chestnut), Alnus (alder), Ambrosia (ragweed), Artemisia (mugwort), Betula (birch), Carpinus (hornbeam), Castanea (chestnut), Chenopodium (goosefoot), Corylus (hazel), Fagus (beech), Fraxinus (ash), Juglans (nut), Picea (spruce), Pinus (pine),
Plantago (plantain), Platanus (plane), Poaceae (grass), Populus (poplar), Quercus (oak), Salix (willow), Taxus/Juniperus (cypress/juniper), Tilia (lime), Ulmus (elm), and Urtica (pellitory).

The highest pollen count of all pollen grain types (trees, grasses, weeds) was recorded in 2008 (Figure 1). Weed pollen dominated in every pollination period with the exception of 2009, when tree pollen prevailed (Figure 2).

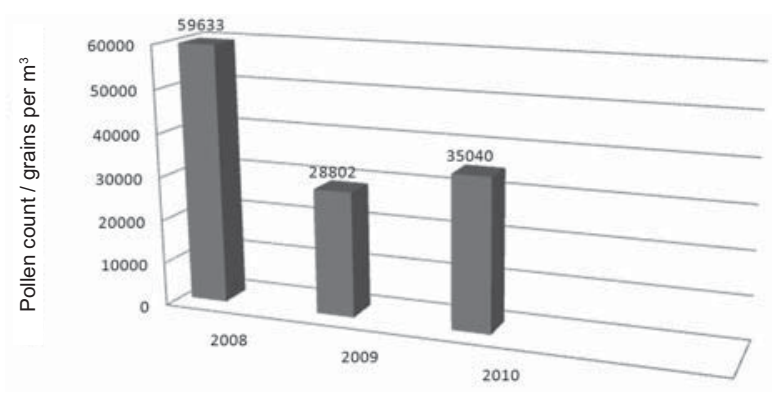

Figure 1 Total pollen counts of all types of plants in the air of Slavonski Brod during the pollination period 2008 to 2010

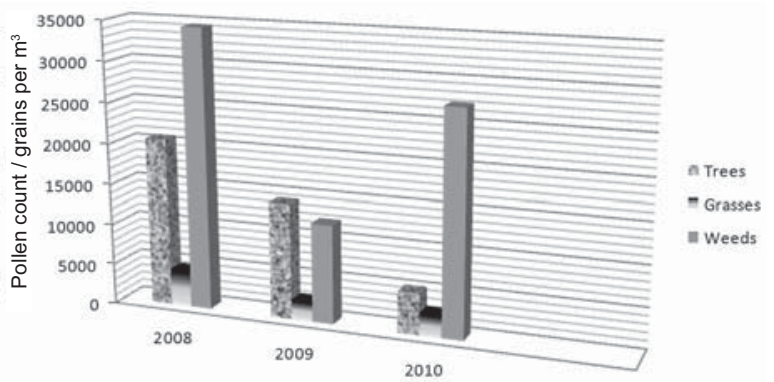

Figure 2 Total pollen counts for trees, grasses, and weeds in Slavonski Brod during the pollination period 2008 to 2010

Figure 3 shows the pollination season for all pollens and all three years. In 2008, tree pollination started in the beginning of March. By the beginning of the summer, it declined and was replaced by much lower grass pollination. This explains why the curve has dropped. In August, weed pollen took over with

Table 1 Pollen rating scale categories (18)

\begin{tabular}{|c|c|c|c|c|}
\hline \multirow{2}{*}{$\begin{array}{l}\text { Pollen rating } \\
\text { scale (PRS) }\end{array}$} & \multicolumn{3}{|c|}{ Pollen density / grains $\mathrm{m}^{-3}$} & \multirow{2}{*}{ Allergy sufferers } \\
\hline & trees & grasses & weeds & \\
\hline low & 1 to 15 & 1 to 5 & 1 to 10 & $\begin{array}{c}\text { extremely sensitive people will have } \\
\text { symptoms }\end{array}$ \\
\hline moderate & 16 to 90 & 6 to 20 & 11 to 50 & many sensitive people will have symptoms \\
\hline high & 91 to 1500 & 21 to 200 & 51 to 500 & most sensitive people will have symptoms \\
\hline very high & $>1500$ & $>200$ & $>500$ & $\begin{array}{l}\text { almost all sensitive people will have } \\
\text { symptoms }\end{array}$ \\
\hline
\end{tabular}




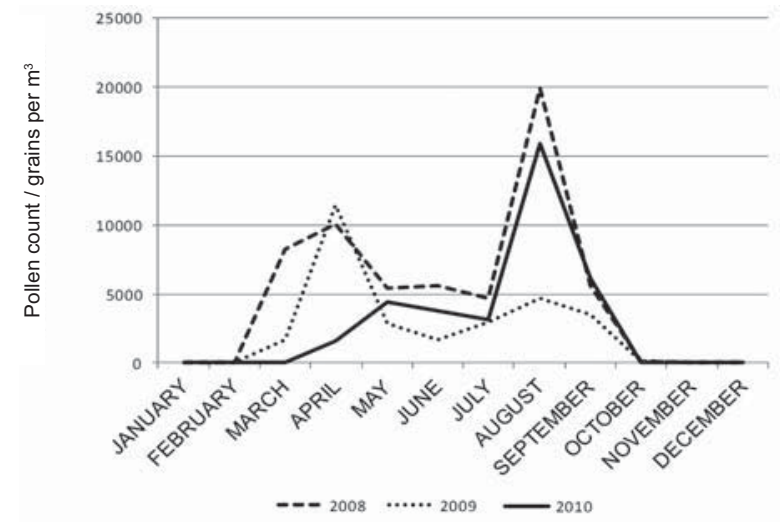

Figure 3 Pollination period of all plant types (trees, grasses, weeds) in Slavonski Brod from 2008 to 2010

a high ragweed pollen count and this is why the curve has risen again. The curve for 2009 looks slightly different, with a higher peak in the spring than in the late summer and autumn, because tree pollen count was higher than weed pollen count. The highest peak in 2010 was reached in August and September, because ragweed pollen count was particularly high that

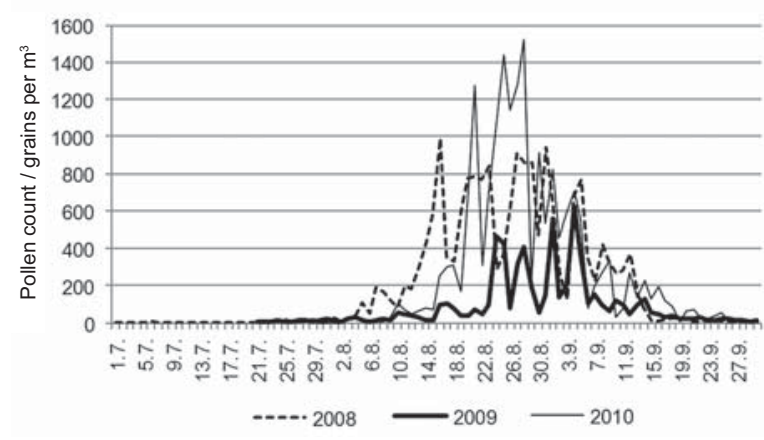

Figure 4 Ragweed pollen counts in Slavonski Brod during the pollination period 2008 to 2010

season, which is even clearer in Figure 4 that shows the pollination of ragweed for all three years.

Figure 5 shows the daily variations in ragweed pollen counts on peak days for every year. The peak concentrations were recorded in the mornings.

Table 2 shows quantitative trends of the main pollen types (period of occurrence, duration, concentration on a peak day, and peak day).

Table 2 Levels of eight dominating plant taxa dominated in Slavonski Brod during the pollination period 2008 to 2010

\begin{tabular}{|c|c|c|c|c|}
\hline Taxa & Period of occurrence & $\begin{array}{c}\text { Duration / } \\
\text { days }\end{array}$ & $\begin{array}{c}\text { Concentration in a peak day / } \\
\text { grains } \mathbf{~ m}^{-3}\end{array}$ & Peak day \\
\hline \multirow{3}{*}{ Taxus } & 2008: 5 March to 1 May & 57 & 134 & 29 March \\
\hline & 2009: 17 March 17 to 29 May & 73 & 1456 & 3 April \\
\hline & 2010: 23 April to 30 May & 37 & 51 & 1 May \\
\hline \multirow{3}{*}{ Betula } & 2008: 9 March to 25 May & 77 & 1836 & 29 March \\
\hline & 2009: 28 March to 15 May & 48 & 276 & 5 April \\
\hline & 2010: 23 April to 27 May & 34 & 47 & 1 May \\
\hline \multirow{3}{*}{ Acer } & 2008: 13 March to 1 June & 80 & 105 & 11 April \\
\hline & 2009: 26 March to 17 May & 52 & 227 & 12 April \\
\hline & 2010: 23 April to 29 May & 36 & 41 & 1 May \\
\hline \multirow{3}{*}{ Platanus } & 2008: 10 March to 4 June. & 86 & 548 & 11 April \\
\hline & 2009: 9 April to 3 May & 24 & 194 & 17 April \\
\hline & 2010: 23 April to 30 May & 37 & 66 & 6 May \\
\hline \multirow{3}{*}{ Quercus } & 2008: 11 March to 11 June & 92 & 135 & 27 May \\
\hline & 2009: 2 April to 30 May & 58 & 137 & 17 April \\
\hline & 2010: 23 April to 1 June & 39 & 115 & 4 May \\
\hline \multirow{3}{*}{ Poaceae } & 2008: 1 April to 13 September & 165 & 249 & 30 May \\
\hline & 2009: 13 April to 13 September & 153 & 165 & 19 May \\
\hline & 2010: 26 April to 11 September & 138 & 156 & 26 May \\
\hline \multirow{3}{*}{ Urtica } & 2008: 14 March to 10 September & 190 & 410 & 14 August \\
\hline & 2009: 8 April to 15 September & 160 & 159 & 16 July \\
\hline & 2010: 29 April to 29 September & 153 & 185 & 15 August \\
\hline \multirow{3}{*}{ Ambrosia } & 2008: 22 June to 26 October & 126 & 994 & 16 August \\
\hline & 2009: 13 July to 15 October & 94 & 625 & 4 September \\
\hline & 2010: 26 July to 15 October & 81 & 1520 & 28 August \\
\hline
\end{tabular}




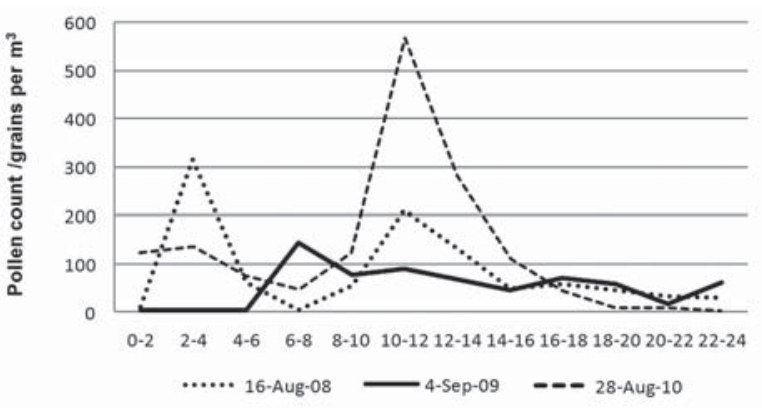

Figure 5 Daily variation of ragweed pollen counts in Slavonski Brod on peak days from 2008 to 2010

\section{DISCUSSION}

Tree pollen types dominated by the taxa Quercus, Betula, Platanus, Acer, and Taxus in the spring coincide with earlier findings in other two continental towns of Vinkovci and Bjelovar $(10,20)$. Grass pollen took over in May and June, as tree pollen counts subsided. Grass pollen counts dominated until July and August to be taken over by weeds, mostly ragweed, followed by the taxa Artemisia, Plantago, and Chenopodium.

The highest ragweed concentration in our study of 1520 pollen grains per cubic meter was recorded on 28 August 2010. For comparison, the highest concentration recorded in continental Zagreb in 2003 was 883 pollen grains per cubic meter (18). In Zadar, a Mediterranean-type town of Croatia, the highest ragweed pollen count in 2008 was 435 grains per cubic meter (21).

Even when ragweed pollination was not in the season (July/August), its pollen count dominated over other weed and in the peak days exceeded 600 to 1500 grains per cubic meter, that is, the threshold (see pollen rating scale in Table 1) associated with symptoms of hay fever or asthma that develop in sensitised patients. This is not surprising, as every single plant of ragweed produces enormous amounts of pollen (18).

On peak days, ragweed pollen counts were the highest in the morning. This pattern is similar to patterns reported in the continental towns of Zagreb, Samobor, and Ivanić Grad (18) and may reflect variations in meteorological parameters, as observed by Recio et al. (9).

\section{CONCLUSIONS}

Considering that the prevalence of allergic diseases is on the rise, and that it is largely related to sensitisation to pollen, there are several ways to reduce the risk of exposure for the general public. One of the measures is stern control of Ambrosia artemisiifolia L. as the most potent allergen source, decreed by the Croatian Ministry of Agriculture, Forestry and Water Management in 2006 (25). This control includes pulling young plants out at the end of May and the beginning of June when they reach $20 \mathrm{~cm}$ in height. Alternatively, during the vegetation period, the plants should be mowed before the pollination season starts (26). Another measure is making information on pollen levels public and regular; this is the task of health ecology services such as our Public Health Institute of the Brod-Posavina County. Clearly, this information should contain advice to physicians and sensitised patients about how to keep exposure at bay and adjust their daily activities and treatment, where necessary (27).

\section{REFERENCES}

1. D'Amato G, Spieksma FThM, Bonini S. Preface. In: D'Amato G, Spieksma FThM, Bonini S, editors. Allergenic pollen and pollinosis in Europe. Cambridge: Blackwell Scientific Publications; 1991. p. IX-X.

2. Sherman WB. Hipersensitivity, Mechanisms and Management. Philadelphia (PA): W.B. Saunders Company; 1968.

3. D'Amato G, Cecchi L, Bonini S, Nunes C, Annesi-Maesano I, Behrendt H, Liccardi G, Popov T, van Cauwenberge P. Allergenic pollen and pollen allergy in Europe. Allergy 2007;9:976-90.

4. Dekaris D. Temeljna alergologija [Fundaments of Alergology, in Croatian]. Zagreb: Školska knjiga; 1983.

5. Kolbas V. Alergologija dječje dobi [Alergology in children's age, in Croatian]. Zagreb: Jumena; 1982.

6. Peternel R, Srnec L, Čulig J, Zaninović K, Mitić B, Vukušić I. Atmospheric pollen season in Zagreb (Croatia) and its relationship with temperature and precipitation. Int $\mathrm{J}$ Biometeorol 2004;48:186-91.

7. Čvorišćec B, Lovašen-Eberhardt Ž. Allergenic pollen and pollinosis in Yugoslavia. In: D'Amato G, Spieksma FThM, Bonini S, editors. Allergenic pollen and pollinosis in Europe. Cambridge: Blackwell Scientific Publications; 1991. p. 221.

8. Middleton Jr E. Allergy, Principles and Practice. $3^{\text {rd }}$ ed. Saint Louis (MO): C.V. Mosby Company; 1988.

9. Recio M, Del Mar Trigo M, Toro FJ, Docampo S, GarciaGonzalez JJ, Cabezudo B. A three-year aeropalynological study in Estepona (Southern Spain). Ann Agric Environ Med 2006;13:201-7.

10. Štefanić E, Rašić S, Merdić S, Čolaković K. Annual variation of airborne pollen in the city of Vinkovci, Northeastern Croatia. Ann Agric Environ Med 2007;14:97-101.

11. Nelson HS, Solomon WR. How ill the wind? Issues in aeroallergen sampling. J Allergy Clin Immunol 2003;112:38. 
12. Hirst JM. An automatic volumetric spore trap. Ann Appl Biol 1952;39:257-65.

13. Bucher E, Kofler V, Vorwohl G, Zieger E. Das Pollenbild der Südtiroler Honige [Pollen images of south Tirol honey, in German]. Leifers: Biologisches labor der landesagentur für Umwelt und Arbeitsschutz; 2004.

14. Grant Smith E. Sampling and Identifying Allergenic Pollens and Molds. San Antonio (TX): Blewstone Press; 1990.

15. Hyde HA, Adams KF. An Atlas of Airborne Pollen Grains. London: MacMillan\&Co Ltd; 1958.

16. Moore PD, Webb JA, Collinson ME. Pollen Analysis. London: Blackwell Scientific Publications; 1991.

17. Weber RW. Pollen identification. Ann Allergy Asthma Immunol 1998;80:141-5.

18. Peternel R, Culig J, Srnec L, Mitić B, Vukušić I, Hrga I. Variation in ragweed (Ambrosia artemisifolia L.) pollen concentration in central Croatia, 2002-2003. Ann Agric Environ Med 2005;12:11-6.

19. Galán C, Cariňanos P, García-Mozo H, Alcazar P, DomínguezVilches E. Model for forecasting Olea europea L. Airborne pollen in south-west Andalusia, Spain. Int J Biometeorol 2001;45:59-63.

20. Devčić M, Jarčov Lj, Devčić-Zglavnik N, Grbić A. Kretanje peludnih alergena na području bjelovarsko-bilogorske županije u razdoblju od 2005. do 2009. godine. [The Occurence of the Pollen in the Region of BjelovarskoBilogorska County in the period 2005-2009, in Croatian] Hrvatski časopis za javno zdravstvo 2010 [displayed 31 May 2010]. Available at http://www.hcjz.hr/clanak. php?id=14192\&rnd=

21. Peroš-Pucar D, Ivandić A, Pucar B. Rezultati mjerenja koncentracije peludi ambrozije na području grada Zadra u razdoblju od 2006. do 2008. godine [Ambrosia pollen Concentration Measured in Zadar Ambient Air During Interval 2006-2008, in Croatian]. Hrvatski časopis za javno zdravstvo 2010 [displayed 31 May 2010]. Available at http:// www.hcjz.hr/clanak.php?id=14248\&rnd=

22. Šikoparija B, Smith M, Skjøth CA, Radišić P, Milkovska S, Šimić S, Brandt J. The panonian plain as a source of Ambrosia pollen in the Balkans. Int J Biometeorol 2009;53:263-72.

23. Makra L, Sánta T, Matyasovszky I, Damialis A, Karatzas K, Bergmann KC, Vokou D. Airborne pollen in three European cities: Detection of atmospheric circulation pathways by applying three-dimensional clustering of backward trajectories. J Geophys Res Atmos 2010 [displayed 31 May 2011]. Available at http://www.sci.u-szeged.hu/eghajlattan/ pdf/MAKRA\%20et\%20al\%20JGR\%202010.pdf

24. Rantio-Lehtimäki A. Short, medium and long range transported airborne particles in viability and antigenicity analyses. Aerobiologia 1994;10:175-81.

25. Naredba o poduzimanju mjera obveznog uklanjanja ambrozije - Ambrosia artemisiifolia L. [Order on measures for compulsory removal of ragweed - Ambrosia artemisiifolia L., in Croatian]. Narodne novine 72/2007.

26. Zavod za javno zdravstvo "Dr. Andrija Štampar". Alergijski semafor, peludna prognoza i peludni kalendar [Allergic scoreboard, pollen forecast and pollen calendar, in Croatian] [displayed 31 May 2011]. Available at http://www.stampar. $\mathrm{hr} /$ AlergijskiSemafor

27. Zavod za javno zdravstvo "Dr. Andrija Štampar". Kako razlikovati pelin od ambrozije? [How to differ mugwort from ragweed?, in Croatian] [displayed 31 May 2011]. Available at http://www.stampar.hr/Default.aspx?art $=1689 \& \mathrm{sec}=150$ 


\section{Sažetak}

\section{KRETANJE PELUDNIH ALERGENA NA PODRUČJU SLAVONSKOG BRODA ZA VRIJEME} POLINACIJSKIH SEZONA 2008.-2010.

Svrha je ovog rada prikazati kretanje peludnih alergena na području grada Slavonskog Broda, s obzirom na to da je pelud jedan od najčešćih prirodnih alergena koji može uzrokovati velike zdravstvene teškoće. Služba za zdravstvenu ekologiju Zavoda za javno zdravstvo Brodsko-posavske županije od kolovoza 2007. godine provodi monitoring koncentracije peludnih zrnaca u zraku na području Slavonskog Broda. Metodologija uzorkovanja peluda standardizirana je volumetrijska metoda. Dnevna koncentracija svih vrsta peluda izražava se kao broj peludnih zrnaca u kubnom metru zraka. Utvrđeno je 25 biljnih vrsta koje se dijele prema podrijetlu na drveće, trave i korove. Najviše peludnih zrnaca (svih vrsta zajedno) zabilježeno je 2008. godine. Prevladavao je pelud korova, s naglaskom na ambroziju. U proljeće se u zraku pojavljuje samo pelud drveća, početkom ljeta pelud trava i korova, dok tokom samog ljeta i jeseni dominira pelud korova. S obzirom na to da se Slavonski Brod nalazi u kontinentalnom dijelu Hrvatske, moglo bi se očekivati da će se tijekom godine u zraku pojaviti pelud svih biljnih vrsta. Kontinuirano praćenje koncentracije peluda u zraku omogućuje pravodobno obavješćivanje javnosti i uvelike može pomoći i liječnicima i pacijentima u preveniranju alergijskih reakcija.

KLJUČNE RIJEČI: aerobiologija, alergija, ambrozija, biljke, Europa

\section{CORRESPONDING AUTHOR:}

\section{Martina Nadih}

Institute of Public Health of Brod - Posavina County

Vladimira Nazora 2a, Slavonski Brod, Croatia

E-mail:martina.nadih@gmail.com 